\title{
Specific Forms of the Safeguarding and Showcasing of Cultural Heritage as Part of Tourism in the High Tatras*
}

\author{
Zdena Krišková
}

\author{
PhDr. Zdena Krišková, PhD. \\ Matej Bel University \\ Faculty of Arts \\ Department of Social Studies and Ethnology \\ Tajovského 40 \\ 97401 Banská Bystrica \\ Slovakia \\ e-mail: zdena.kriskova@umb.sk \\ ORCID: 0000-0003-1977-3145
}

Muzeológia a kultúrne dedičstvo, 2021, 9:2:61-77

DOI: $10.46284 / \mathrm{mkd} .2021 .9 .2 .4$

\begin{abstract}
Specific Forms of the Safeguarding and Showcasing of Cultural Heritage as Part of Tourism in the High Tatras

This study describes a variety of approaches to communication by museums involved in cultural heritage exchange. It focuses on the High Tatras region, which is the most important centre of tourism in Slovakia. It also looks at the specifics of how tourism developed in the region.

The data was collected over a multi-year series of ethnological field research trips, and primarily conducted by means of structured interviews, oral histories and participatory observation. The paper concentrates on shifts in the area of museum communication, from the classical interpretative approach towards exhibitions that present their subject matter in a more flexible way, with a focus on emotional experience. The article aims to use some chosen case studies of small, independent museums and galleries from the town of Vysoke Tatry, in the High Tatras, to highlight the importance of sustainability, especially in terms of the growth of tourism.
\end{abstract}

Keywords: museum, tourism, cultural tourism, cultural heritage

\section{Introduction}

One of the main determining factors of human development in all crucial political or economic processes in the world is the need to respect the ethnic and cultural diversity of communities, the key factor being the knowledge and understanding of different cultures. In terms of the travel industry, it is the cultural core of ethnic groups that is the starting point in the process of learning about them with respect to a particular geographical space. Memory institutions play an indispensable role in this process.

The preservation of the cultural and natural environment is one of the key priorities of the travel industry and tourism, and relates to sustainable tourism and sustainable development issues as well. Sustainable tourism - also known as soft tourism, green tourism or responsible tourism - is characterised by the exploitation of and respect for local natural and cultural resources. It thus has a positive effect on the preservation of cultural identity and cultural diversity. ${ }^{1}$

\footnotetext{
* This study has been produced under grant project VEGA 1/0232/19 Cultural heritage as part of the socio-cultural potential of tourism development within local communities.

${ }^{1}$ CHRENŠČOVÁ, Viera. Udržatel’ný rozvoj cestovného ruchu v chránenej krajinnej oblasti Horná Orava z pohl’adu aktérov rozhodovacej sféry. In: Acta Universitatis Matthiae Belli. 2011, pp. 61-62. www.fpv.umb.sk/
} 
The issue of cultural tourism resonates in these contexts. In this form of tourism, which takes place on both the domestic and international level, the subjects of interest tend to include the discovery of tangible heritage, such as historical monuments, as well as intangible heritage, expressed through the cultural landscape of the destination and experienced through activities which authentically reflect the cultural history of a community. ${ }^{2}$

Based on this framework, this study aims to explore the transformation, safeguarding, presentation and, in particular, the use of cultural heritage values within the environment of the town of Vysoke Tatry, while considering the background of the travel industry and tourism. It is in this context that we focus on the subject of this study: a special type of museum whose mission is to obtain, preserve, manage and present to the public original tangible evidence of cultural and natural development and which, from the perspective of accepting fundamental scientific museological principles, represent a specific form of presentation. Through some examples of such museums in Vysoké Tatry, we explore the degree to which they fulfil their core mission of safeguarding and showcasing cultural heritage in the context of the development of sustainable tourism.

Our approach focuses on specialised memory institutions, and examines the cultural links of the travel industry and tourism to a particular place, and on the relationship and use of that place's cultural values in the process of sustainable development. Cultural value ties often become inconsistent with the economic priorities, including the equally threatened environmental essence of a place.

The data presented and analysed in this report isprimarily sourced from a series of ethnological fieldwork projects conducted in 2019 and 2020, with a primary focus on direct structured interviews with key figures in cultural institutions, local government and tourism organisations oriented on the town of Vysoké Tatry. In order to ensure the protection of personal data, we only provide basic information about gender and age and, where necessary, the respondent's role in the process under discussion. The methodology also involved direct participation or observant participation, in the case of visited activities and events.

Nowadays, most human societies regard the travel industry as an integral part of their complex development. The travel industry can be defined as a "set of activities aimed to satisfy people's needs related to travel and staying outside their permanent residence, usually during their spare time, for the purpose of rest, learning, amusement and entertainment". ${ }^{3}$ It is a system determined by the external environment and by dominant prevailing systems, one of them being the cultural system. ${ }^{4}$ The cultural aspects of the travel industry can be described as positive, and often determine its realisation.

If we approach the travel industry as a socio-cultural phenomenon and explore it, for example, in the context of cultural heritage and local culture, then it is appropriate to replace the term travel industry (as a set of services) with the term tourism (oriented on people and society). ${ }^{5}$

This is the basis from which we will observe the specific features of museums' activities with regard to the presentation of cultural heritage.

\footnotetext{
2 TOADER, Cosmina-Simona, SAMBOTIN, Dana, GHERMAN, Dana. Aspects regarding cultural tourism development in Timiş county through projects. In: Agricultural Management /Lucrari Stiintifice Seria I. 2013, pp. 56-63.

${ }^{3}$ GÚČ́IK, Marián et col. Manažment cestovného ruchu. 2006, p. 4.

${ }^{4}$ GÚČIK, Marián et col. Manažment regionálneho cestovného ruchu. 2007, p. 5.

${ }^{5}$ CHORVÁT, Ivan. Sociológia turizmu a jej počiatočné východiská. In: Tradičná kultúra, turizmus a rozvoj regiónov. 2006, p. 196.
} 


\section{Description of the research site from a geographical, economic, and ethnic perspective}

The vast geographical territory of the High Tatras Mountains is a natural part of Slovakia's northern border with Poland. Their complex boundaries are linked, not only in an administrative and geographical sense, but also in cultural terms, with overlapping cadastral boundaries of several neighbouring municipalities and towns. ${ }^{6}$ With an area of 37,988 hectares, the administrative centre of the modern town of Vysoké Tatry (literally High Tatras) was formed by the gradual establishment of Tatra settlements within the cadastral areas of Starý Smokovec, Nový Smokovec, Horný Smokovec, Dolný Smokovec, Tatranská Lomnica and part of Štrbské Pleso.

Today, the mountain range attracts the attention of visitors mainly due to its opportunities for hiking and winter sports. Aside from the specific features of the natural environment, the primary reason the first Tatra settlements were established was to make use of the local healing springs. In contrast to the prevailing agrarian nature of traditional Slovakian culture, the spa resorts were the main economic driver in the High Tatras. The first settlements were gradually followed by the growth of the hotel industry, accompanied by the development of sports and hiking. ${ }^{7}$

Slovakia, lying on the boundary between Eastern and Western Europe, has never been a homogenous unit in terms of ethnicity, religion or culture. It constituted a crossroads of various ethnic groups and cultures, which have all left a mark on its culture. ${ }^{8}$ The initial interest in the Tatras came predominantly from members of the intelligentsia, researchers and scientists, travellers and artists. The wider, historically conditioned ethnic ties relate to the members of the German, Hungarian or Czech ethnic groups.

The administrative unit of Vysoké Tatry can be delineated by the gradual establishment of individual Tatra settlements since the end of the eighteenth century. The oldest Tatra settlement - and the only one until the opening, in 1872, of the Košice-Bohumín railway line along the foothills of the Tatra mountains - was Starý Smokovec, established in 1797. From the beginning of the twentieth century, it was a spa town; it also, in the same period, became the first official winter sports centre in the Kingdom of Hungary, of which it was a part until 1918. ${ }^{9}$ Strbské Pleso settlement (1872) acquired the official status of a healing spa for climatic treatment in 1885, after a bath house was opened there. ${ }^{10}$ The establishment of Tatranská Lomnica in 1892 related to the opening of the first state climatic spa in the High Tatras. ${ }^{11}$ These areas form the basis of the current urban centre, which was founded in 1957 and also includes several smaller Tatra settlements.

From a contemporary perspective, the fall of communism in 1989 marked a major turning point for the travel industry and tourism in the High Tatras. As a result of the economic changes mainly in the field of property ownership laws the High Tatras faced a period of chaotic development, lacking a comprehensive strategy. At first, the emerging market mechanisms were

\footnotetext{
6 ŠTURCEL, Marián. Príroda Tatier. In: Vysoké Tatry. 2017, p. 15.

${ }^{7}$ The healing effects of the acidic and thermal waters of the Spiš region were described by a doctor, Ján Žigmund Kreysel, back in 1764 (BOHUŠ, Ivan, st., BOHUŠ, Ivan, ml. Tatranské osady do r. 1918. In: Vysoké Tatry. 2017, p. 49).

${ }^{8}$ BITUŠÍKOVÁ, Alexandra. Kultúrne dedičstvo a regionálny roẓvoj: Etnologická perspektivia. 2008, p. 38.

${ }^{9}$ BOHUŠ, Ivan, st., BOHUŠ, Ivan, ml. Tatranské osady ..., p. 49.

${ }^{10}$ BOHUŠ, Ivan, st., BOHUŠ, Ivan, ml. Tatranské osady ..., p. 52.

${ }^{11}$ BOHUŠ, Ivan, st., BOHUŠ, Ivan, ml. Tatranské osady ..., pp. 59-60.
} 
used mainly by entrepreneurs as well as some original land owners, with the primary objective of achieving high profits. But many proved unable to cope with the new situation, starting projects which ended in failure and allowing a plethora of cultural objects to fall into ruin. As a result, the number of visitors declined at the beginning of the 1990s, which was something of a paradox given the opening of the borders significantly facilitated the entry of foreign visitors. ${ }^{12}$

\section{The specific features of the cultural heritage of the High Tatras as interpreted} by memory institutions

In the context of the socio-cultural importance of the travel industry, one of the primary aspects is the interpretation of the features of a visited site. In the case of the High Tatras, the objectives of present-day visitors include hiking and sports. However, the demands of modern visitors include a much broader knowledge of the place, mutual relationships, the links between past and present, the culture, and the life of the communities that characterise it.

The transformation and interpretation of cultural heritage in connection with tourism is an information-intensive activity, requiring a deep knowledge and understanding of the site's cultural values. Professionals in this field must also pay attention to current trends in travelling and the requirements of tourist. ${ }^{13}$ Several authors confirm the existence of the educational aspects of cultural tourism, where the interest of participants is focused on the life of the local communities voluntarily and in a targeted way. Learning aside, visitors also find entertainment and leisure elements in cultural tourism. Together with other forms of capital - physical, natural, human, economic, and social - cultural heritage constitutes a principal source which can be used for promoting the sustainable development of a region. ${ }^{14}$

The safeguarding and subsequent showcasing of the cultural elements typical of the High Tatras is a prerequisite for knowing and understanding life in this region. This aim is apparent in several institutions within the town of Vysoké Tatry, including some memory institutions, with TANAP Museum in Tatranská Lomnica being the oldest and most famous one. The museum continued the traditions of the Hungarian Carpathian Society with the establishment of the Carpathian Museum in Poprad in the 1880s. The current TANAP Museum is managed by the State Forests company; its collection contains mainly natural exhibits, but also includes some ethnographic collections from the High Tatras area. The museum houses almost 138,000 items and archival documents. ${ }^{15}$ As a traditional brick-and-mortar museum, it is an important communicator of life in the High Tatras in the context of tourism.

The objective of this study is to focus attention on a smaller, specific type of memory institution, that is, museums formed as a result of individual activities by enthusiasts interested in life in the Tatras, across various fields of enquiry. They are mainly private institutions which, due to their legislative and organisational structures and marginal adherence to museological principles, differ from traditional museums in a number of ways. Their exhibitions, which provide a documentary record of the region's development, are complemented with participatory

\footnotetext{
${ }^{12}$ KRIŠKOVÁ, Zdena. Kultúrne dedičstvo - ekonomický zdroj rozvoja turizmu, či odraz kultúrnej identity? In: XXIII. Medzinárodné kolokvium o regionálnych vedách. 2020, pp. 364-365.

${ }^{13}$ KURPAŠ, Michal, ZIMA, Roman. Manažment a marketing kultúrneho dedičstva. In: Kultúrne dedičstvo a identita. 2016, p. 72.

${ }^{14}$ DUGULAN, Diana, POPESCU Ioana Cecilia, VEGHES, Calin. An assessment of the relationship between the cultural heritage, travel and tourism, and sustainable development in the Central and Eastern European counties. Annals of Faculty of Economics, University of Oradea, Faculty of Economics, 1(1), pages 1141-1147.

${ }^{15}$ CHOVANCOVÁ, Barbara. Sprievodca expozíciou múzea TANAP-u. 2015, p. 7.
} 
activities which form a key part of their work. They concentrate on showcasing specific features that characterise the development and culture of the Tatras. For both domestic and foreign visitors, these museums contribute, with these small fragments, to our understanding of the complex mosaic of life in the Tatras, and undoubtedly form a significant part of the region's cultural memory.

These institutions include the Museum of Tatra Cinematography and Photography and the Museum of Mountain Porters in Starý Smokovec, and the Ski Museum in Tatranská Lomnica. Despite their inconspicuous position in the local life, the creators of the collections, as experts in the given field and, in particular, as enthusiasts and lovers of the nature and culture of the Tatra region, give them a touch of significance. Each of them is devoted to a different phenomenon identified with Tatra culture.

\section{The Museum of Tatra Cinematography and Photography}

The Slovak High Tatras became the subject of interest of photographers and painters as early as the nineteenth century. The first protagonists, in the 1870s, included Karol Divald Snr, ${ }^{16}$ Juraj Weinciller, Milan Legutky and Viliam Malík. The unique pictures taken by these legendary Tatra photographers later became the foundation of the museum. They form a valuable documentary and artistic component of the historical memory of the mountains and preserve a unique record of the region's cultural heritage.

In terms of acquisitions, some of the exhibits were purchased from private collections, some donated, and some are on long-term loan from the family collections of the photographers' descendants.

The museum itself was founded in 2015 by four enthusiasts with an interest in photography and the Tatras: Michal Machala, Ján Fečík, Milan Mat’ašovský and Leo Weinciller. It initially presented their private collections, but gradually expanded with new additions. The fonders' intention was to introduce to the public people who were active in the field of Tatra photography, and later cinematography, going all the way back to 1870 . The collections detail the atmosphere of the Tatras and the transformations the region has undergone, as captured by camera lens. They also document themes relating to life in the mountains, including specialist local professions such as mountain climbers, rescuers, guides, porters and so on. ${ }^{17}$

The exhibition also focuses on the art of cinematography and photography, demonstrating the evolution of cameras since the nineteenth century. The Eastern European region is predominantly represented here (in particular, Czechoslovakia, the Soviet Union and East Germany). Since the purchase of equipment from abroad was rather complicated in Slovakia during the communist era, the collection only contains a few objects of Japanese or US provenance.

In 2015, the town offered the museum the opportunity to rent two small exhibition spaces in the centre of Starý Smokovec. These premises are located in the reconstructed building of a national heritage site, the former Vila Alica bath house, ${ }^{18}$ which has been under new ownership since 2018. The miniature spaces of this originally log building, created by architect Gedeon Majunke, currently serve as the seat of the Tourism Association, the Mountain Porters' Office, and the Municipal Library.

\footnotetext{
${ }^{16}$ NOVÁKOVÁ, Katarína. Tatranski nosiči. 2015. p. 14.

${ }^{17}$ JANIGOVÁ, Ingrid. Spoločenské dianie a kultúra. In: Mesto Vysoké Tatry. 2017, p. 302

${ }^{18}$ The villa was initially known by the Tatra inhabitants as Szilagyi Vila; in 1918, it was renamed after the daughter of the then President of the Czechoslovak Republic, T. G. Masaryk - Alica.
} 
From a legislative point of view, the museum is private and is not listed in the Register of Museums and Galleries of the Slovak Republic, kept by the Ministry of Culture. ${ }^{19}$ Today, this originally non-profit organisation is run as an entity with a trade licence.

Given the private nature of this institution, the professional administration of the collection items is not performed in accordance with the official legislative standards of first- and secondinstance documentation. The collections are identified based on descriptions containing background information provided by their former owners. The owner of the museum appears to be caught in an extended process of setting up a simplified collection registration system based on a personalised and idiosyncratic approach, rather than the widely accepted professional standards for cataloguing.

The limited space, which simultaneously serves as reception office, exhibition and depository, complicates the protection of the collections. Unexhibited objects are stored in the lower lockable part of the display cases. On the other hand, the wooden building is an advantage in terms of maintaining the appropriate humidity and temperature to preserve the items.

As far as presentation activities are concerned, the permanent exposition is complemented with regularly changing thematic exhibitions of photographs and other works, with a focus on domestic artists from the Tatras.

The museum is known for organising numerous complementary activities focused on gaining a more intimate, deeper perspective on life in the Tatras. These include film screenings, lectures and debates involving famous individuals from the Tatras or dedicated to figures who have contributed to the region's cultural growth and the promotion of its visibility.

The specific interest in culture, especially thematic [aspects], of which this museum is a part, is being formed extremely laboriously and slowly. Thanks to the fact that the events are held in this central place, there are also people who would otherwise not come specifically to this museum. Even though a group of permanent fans is being formed step by step, it is a difficult, long-term process built mainly through personal contacts. It is mainly domestic visitors who prevail in this process. (Woman, 35 years)

In general, the distribution of promotion materials is one of the principal pillars supporting the growth of tourism in the region. In this regard, the Museum of Tatra Cinematography and Photography focuses its marketing activities almost exclusively on the domestic tourism market. In terms of selling souvenirs or mementos, the museum offers DVDs, films, photographs and books issued by local publishing houses.

Giving people food and accommodation is too little. There is a trend towards experience travelling, and this is what I'd like to offer people. My intention is not only to preserve the museum, but to make it lively, offer activities, invite people to different kinds of programmes of non-commercial culture which visitors would not see elsewhere, just here. This is what

\footnotetext{
${ }^{19}$ The Ministry of Culture lists in the Register of Museums and Galleries of the Slovak Republic the museums and galleries which meet the following conditions for the performance of basic professional activities, in compliance with Act No. 206/2009 Coll. on Museums and Galleries and on Objects of Cultural Value: a) keep chronological, expert records of collection items of level I; b) create the conditions for the security of collection items, as per Article 12, and professional protection of collection items as per Article 13 of the Museum Act; c) arrange the presentation of collection items and collections by means of permanent exhibitions, long-term, short-term and travelling shows, publishing and editing activities or other expert, educational and presentation activities; d) deploy qualified staff for the performance of basic expert activities. The Ministry of Culture SR. Register of Museums and Galleries. http://195.49.188.210/kulturne-dedicstvo/muzea-a-galerie/
} 
I'd like to initiate, but I've only been here for a short time. Two years in tourism, it's nothing. (Woman, 35 years).
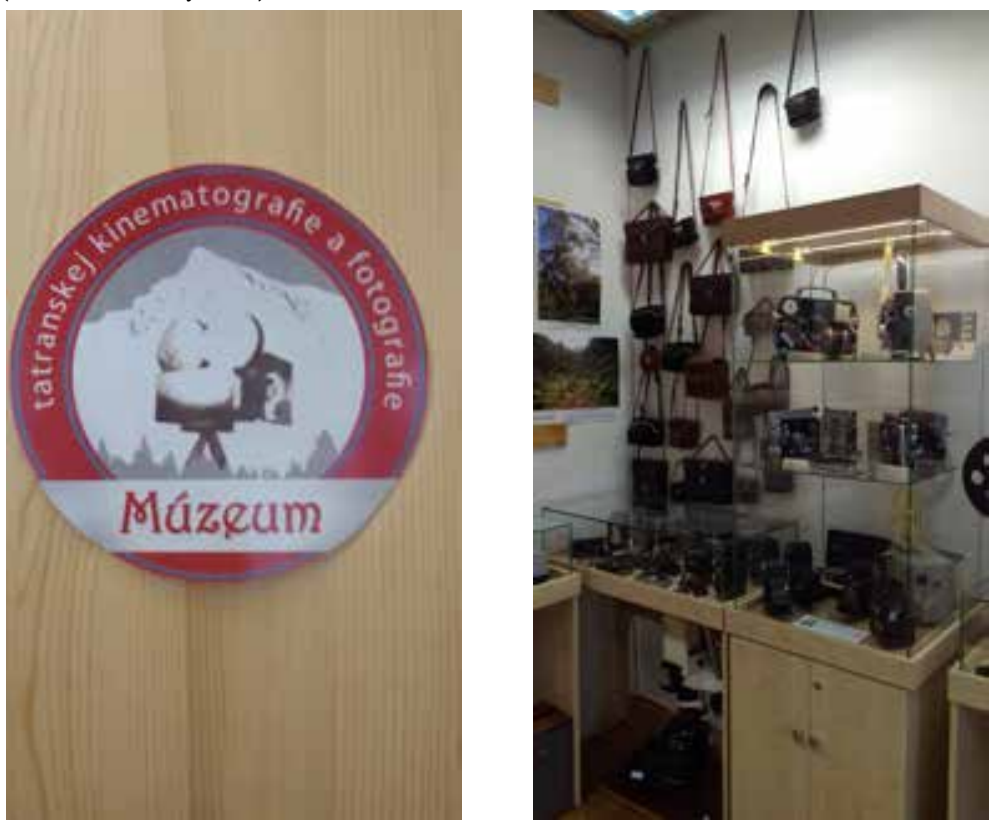

Fig. 1, Fig. 2: Museum of Tatra Cinematography and Photography.

Photo: Z. Krišková, 2020

\section{Museum of Mountain Guides and Porters (Sherpa Museum)}

Another private "mini-museum", commonly known as the Sherpa Museum, has served the public since 2014. It is located within the Swiss House, the oldest preserved building in the town of Vysoké Tatry, built in 1856, and focuses on one of the dominant elements of life in the Tatras - the profession of mountain guides and porters.

Mountain guides, as local experts on the Tatras, stood at the foundation tourism's development in the region at the turn of the twentieth century, disseminating knowledge of the area and enabling visitors to access the peaks, mountain lakes and other previously inaccessible or unknown corners of the High Tatras. The profession of porter was gradually separated from that of mountain guide, with a specific focus on carrying the technical equipment of the first explorers and artists, the personal belongings of visitors and, later, food supplies and furnishings for remote tourist chalets. It is important to note that this mountain profession has been included in the Representative List of the Intangible Cultural Heritage of Slovakia, as a special element of cultural identification associated with life in the Tatras.

The private Sherpa Museum was founded, and is still run, by Štefan Bačkor, a mountaineer and former porter who has a close relationship to this theme, having carried loads to mountain chalets himself for 18 years.

The idea of the mountain porters' museum is to record traces of the highest number possible of still active, as well as legendary porters in the Tatra valleys, describe their activities and perhaps their fates. Many of them are no longer with us and drag their loads along heavenly paths. This is why I immodestly expect support from active as well as passive porters and their fans. I'll be happy if you leave a story here, an interesting artefact or just a bit of that contagious "lightness of being". (Man, 42 years) ${ }^{20}$

${ }^{20}$ Museum of Mountain Guides and Porters: www.sherpacaffe.sk/ 
In terms of the collection items, all elements are part of the owner's private collection. They can be found in the museum's single small exhibition room, which also serves as a depository and a venue for lectures and film screenings. Since these activities represent the primary intent of the owner, they cannot really be described as accompanying or complementary. The owner complements the museum's activities with an offer of corporate team-building events which include the chance to try load carrying in practice.

The collection offers an overview of the evolution of portering equipment and tools, showing specialist equipment, from footwear to climbing accessories. The exhibition contains several rare exhibits, including a frame backpack used by Wehrmacht soldiers in World War II).

The museum is also special when it comes to the administration of collections, this is not undertaken to a level that meets the legal requirements for museums listed in the Register of Museums under the Ministry of Culture of the Slovak Republic. The records are exclusively a matter of the owner's memory. The premises are rented to the museum by the municipal authorities of Vysoké Tatry. A small café, a children's corner, and available accommodation in the form of two rooms with a kitchen on the first floor underlines its family atmosphere.

The primary activities of the institution include the event Nosičská stovka (Porters' One Hundred), held at the beginning of the season to preserve the memory of the porter Juro Petranský, and Sherpa Rally, which closes the season. Both competitions involve carrying loads to Zamkovskýs Chalet. These events have developed the tradition by encouraging active participation by members of the public. This lively, interactive approach promotes the creation of a permanent relationship with the portering tradition, and helps to establish and strengthen contacts between individuals who are interested in this mountain profession. This continuity of cultural elements undoubtedly contributes to the essential mission of safeguarding and using cultural values in the sustainability process.

The cultural institution also owes its success to its cooperation with the town's representatives; for example, the museum organises a Porters' Day as part of the Days of the Town festival.
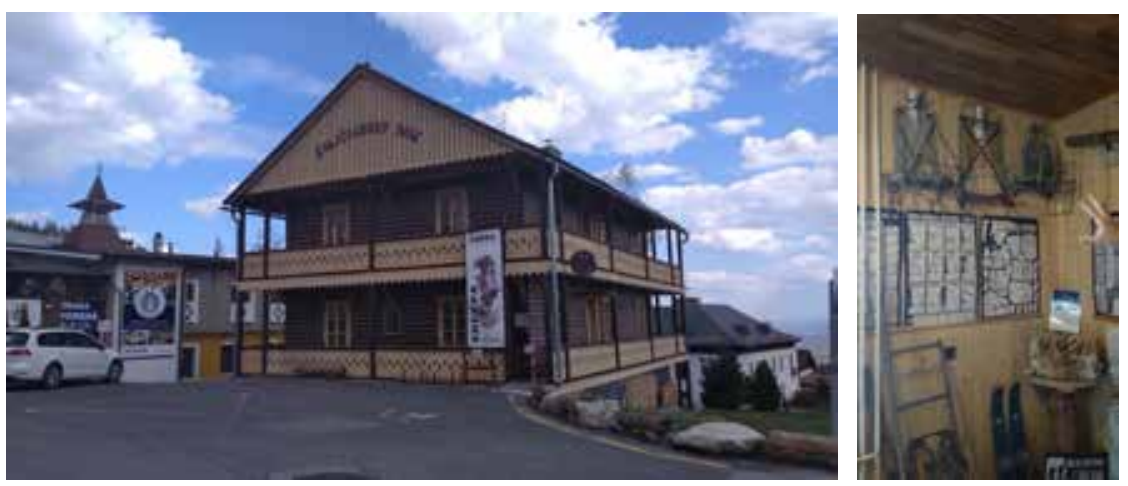

Fig. 3, Fig. 4:

Sherpa Museum.

Photo: Z. Krišková, 2020

\section{Ski Museum}

The sports museum is a memory institution focusing on the documentation and interpretation of the past and present of sports in the Tatras (even though its name gives the impression of a seemingly narrower thematic focus). It is located in the centre of the town of Vysoké Tatry, in the Tatranská Lomnica cadastral area. ${ }^{21}$

The owner and founder of this private memory institution is an active sportsperson (as is

${ }^{21}$ JANIGOVÁ, Ingrid. Spoločenské dianie a kultúra. In: Mesto Vysoké Tatry. 2017, p. 301 
his wife), a native of this region, and a proud local patriot with close personal links to the Tatras and sports. The owner's cultural roots, love for sports and the Tatras, and his professionalism radiate from every object and display cabinet, through the sensible design of the exhibition space and obvious care given the exhibits. His knowledge of the theme, and his great enthusiasm, is apparent in the detailed commentary on each of almost 600 pairs of skis and other tangible objects, photographs and accompanying documentation materials. The motivation to establish the museum was very prosaic:

Some thirty years ago, I had a restaurant called Slnečný dom (Sun House). We put skis on the wall; there were enough old skis everywhere. When a visitor once asked for more details about them, I didn't know what to tell him: well, some wooden skis. This was that impulse. I started to search for information, collect skis, search for information in literature, on the internet; I spent hours sitting and studying... Today, I immodestly think that, in Slovakia, there is no greater expert in skis. When anyone sends me a picture, I can tell you straight away what kind of ski it is, from which year, what kind of tying, the approximate value... (Man, 52 years)

This family-oriented museum opened in 2013 on the ground floor of a recently restored building in the centre of Lomnica, which the owner purchased. The building includes a small café and a sports store in the basement.

Among the institutions mentioned in this study, the Ski Museum is the only official member of Slovakia's museum network, listed in the Register of Museums and Galleries of the Slovak Republic. However, in legislative and organisational matters, it maintains an individual form of ownership without any formal museum statutes, even though this means certain restrictions apply when it comes to obtaining state subsidies. The museum cooperates closely with the Slovak Olympics and Sports Museum in Bratislava, mainly through expert consultations.

Regarding acquisition and management of the collections, most items are private property obtained mainly through purchase or donation. At present, the collection contains approximately 5-6,000 tangible items, in addition to photographs and documentation. The museum's philosophy regarding acquisitions is to focus on items that link exclusively to the themes of the Tatras and sports. In the context of tourism, especially international tourism, this approach helps to attract the interest of visitors, due to the museum's evident authenticity, originality and special ties to the environment.

Regarding the documentation of collections, the museum uses its own recording system, just as in the previous case. The owner takes great care to protect documents from mechanical damage by storing them systematically in special wooden crates in a private depository.

Items awaiting conservation are also stored in a separate room; they are treated by the owner himself or, in more complicated cases, in collaboration with professional conservation companies in Slovakia (Levoča) and the Czech Republic (Prague).

The museum's presentation activities for the public take the form of a permanent exposition which partly varies from time to time. Throughout the year, the permanent portfolio is complemented with four or five temporary thematic exhibitions.

Footfall at most of these institutions is an important issue. In this context, the Ski Museum's strategy relies on it being situated in the centre of the settlement.

Those European museums (like the big museum in Murzzuschlag, Austria), when they told me that their annual attendance is 10,000 people, it would be zero for us economically; I realised that we needed to have over 15,000 people to survive. Right in the first year, our attendance was around 18,000, which we have more-or-less maintained until the present. (Man, 52 years) 
Groups of children are among the most common type of visitor: in winter, the museum sees mainly ski course participants, and later in the year, those attending open-air schools. Such visitors come predominantly from Slovakia, although it can be difficult to measure this precisely, since the courses are usually organised for large groups which may include visitors from abroad. As for foreign visitors, a substantial proportion attend as individuals.

The key determinants affecting footfall include the weather, since the Tatras, in their essence, are tied to hiking and outdoor sports. Museum institutions in the area offer additional indoor programmes in case of bad weather or for after-ski relaxation. However, even in a large resort such as the High Tatras, small private museums often struggle to survive economically.

To increase attendance, the museum tried offering extended opening hours in winter, staying open until 22:00 (its usual year-round opening hours being 09:00-18:00), in the hope that this might better fit the schedule of skiers.

We assumed that they would have a dinner after skiing and that they wouldn't have much to do in the evening, and so they could come to visit us. Unfortunately, we are not located at a mountain resort with shops open during the evening and with a centre full of entertainment. Nobody would stick his head out of the hotel. (Man, 52 years)
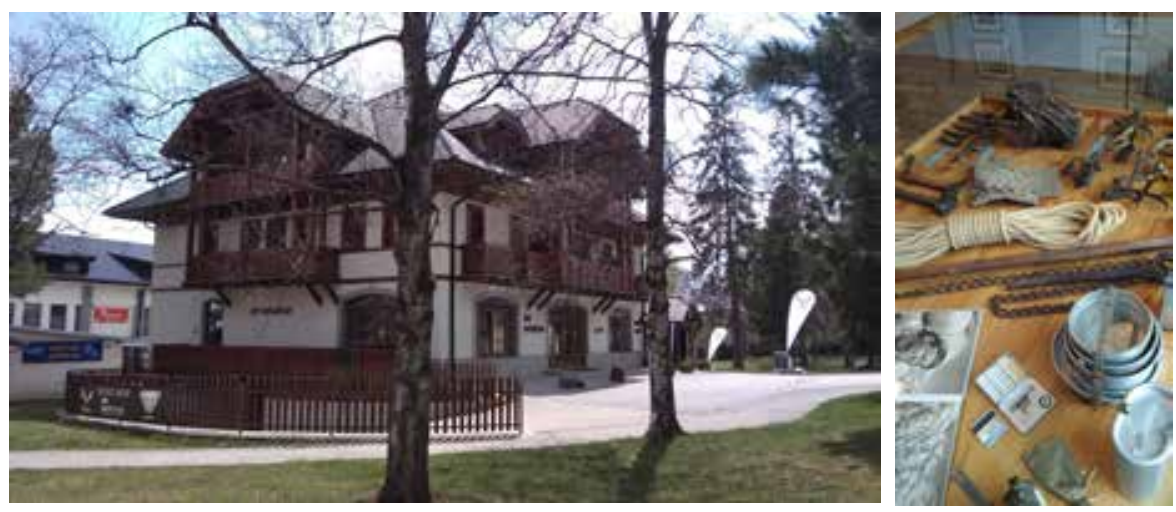

Fig. 5, Fig. 6:

Ski Museum.

Photo: Z.

Krišková, 2020

Nevertheless, random visitors still represent the largest majority. The number of visitors with a specific interest in skiing has been rising. Tourists often study the museum's offer in advance and choose what they wish to see. Social networks, the internet and, in particular, partner associations (Tourism Associations, Regional Tourism Organisation, Tatras Region) make a substantial contribution in this regard. The Wander Card project also contributes to promoting the visiting of these specialist museums. ${ }^{22}$

The memory institutions listed in this study all represent specific approaches to showcasing various aspects of the High Tatras' cultural heritage. They are not run on the standard legislative and organisational basis of traditional brick-and-mortar museums, and the management of the collections is subject to the owners' individual rules.

What is common to all of them is the professional approach of the owners, their close relationship with the subject matter, their enthusiasm, and their efforts to present their collections through complementary interactive activities for visitors. Another characteristic

\footnotetext{
${ }^{22}$ This is related to the Wander Book project, and provides a comprehensive and permanently developing network presenting interesting information on tourism, culture, sports and gastronomy. Thanks to its translation into several languages, the project also supports visitors from abroad. Wander Book was founded in the Czech Republic in 2008 by the orienteering runner and dedicated photographer Ing. Rudolf Ropek. https://sk.wander-book.com/co-suwander-card.htm
} 
feature of museum work that has survived until the present is their volunteer nature - in particular, the fact they were started by amateur enthusiasts, rather than museum professionals. ${ }^{23}$ Nevertheless, their common objective is to build a relationship to the Tatras by sharing their cultural values.

\section{Lomnica Gallery}

Lomnica Gallery, located in Hotel Lomnica in Tatranská Lomnica, presents a specific and, undoubtedly, special approach to safeguarding and showcasing the cultural values of the High Tatras. Even though this study's main focus is not on the architectonic contexts of tourism, we shall make a brief exception in this case, as it is a special example of continuity of preservation and simultaneous use of cultural heritage combined with architecture and fine arts.

Hotel Lomnica, built in 1893, was the first hotel facility in Tatranská Lomnica. For this reason, but also thanks to its character and the high quality of service it offers, it has been called the "First Lady" of the Tatras. The building, a unique design by the Spiš architect Gedeon Majunke with elements of the Alpine Art Nouveau architectural style, is listed in the Register of Immovable Monuments of the Slovak Republic. ${ }^{24}$

By the end of the twentieth century, after changing hands several times due to the failed economic ambitions of a series of owners, the building has ended up in a state of disrepair. The current owner launched a general restoration of "its body as well as spirit" and, in 2016, it "rose from the ashes like a phoenix", as the locals say.

The current owner carried out some thorough qualitative research, having consulted the chronicles and records of other Tatra hotels. He surveyed local inhabitants and former employees, providing valuable data. By means of local and regional media, a website and the assistance of regional organisations, he launched the campaign PamätnícihotelLomnica.sk to obtain and summarise relevant documents.

After its restoration, which took around 20 months, the hotel launched the new era of its existence in 2016 with a meeting for the former workers and the new young team which would be working there. This approach, which placed emphasis on maintaining continuity and the transmission of cultural values, also contributed to the opening of the Lomnica Gallery.

Lomnica presents the unusual combination of staying in the hotel and the chance to view its gallery collection, which is loosely exhibited in the public areas of the building, in the corridors and in the rooms. The collection was, from the outset, conceived as an integral part of the restoration and functioning of Hotel Lomnica, which was a jewel of the Austro-Hungarian Monarchy's heritage. Drawing on the idea of the renaissance of the spirit which characterised that era, the plan was to exhibit Slovak and other Central European works of art, alongside a historic overview that could capture the transformations of the period as reflected by visual artists. $^{25}$

The collection presents to the hotel guests, as well as walk-in visitors and tourists, the precious and important examples of Slovakia's cultural heritage through the works of the most prominent artists of that period. Landscape painting, prioritising Tatra themes, is a feature of the works of important representatives of several artistic currents, including L. Medňanský,

\footnotetext{
${ }^{23}$ TIŠLIAR, Pavol. Muzeológia na Slovensku. In: Muzeológia a kultúrne dedičstvo. 2016/1, p. 127.

${ }^{24}$ It was listed in 1963 (No. 3862/1) as one of nearly 80 immovable cultural heritage sites in the town of Vysoké Tatry. Ministry of Culture SR. Register of Museums and Galleries. http://195.49.188.210/kulturne-dedicstvo/muzeaa-galerie/

${ }^{25}$ KVASNIČKA, Marián. Úvodné slovo ku zbierke. In: Galéria Lomnica 2017, p. 12.
} 
N. Katona, J. Alexy, D. Skutecký, G. Mallý, V. Hložník, J. Hála, M. Benka, M. A. Bazovský, J. Kompánek and many others.

The exhibition includes documentation focused on the history of the hotel and related life and events in the Tatras, including important milestones in the region's development, mainly in connection with sports. The documentary exhibits include contemporary photographs, collectors' items such as old postcards of the Tatras and objects related to the history of the hotel, as well as several architectonic fragments discovered during the reconstruction.

Lomnica Gallery is officially listed as a gallery institution in the Register of Museums and Galleries of the Slovak Republic. It has its own system for collections management with regard to records and documentation in place.

In this institution, the greatest attention is paid to the security of the gallery's collection, given the value of the original works of art, some of which are owned by the hotel, while others are on temporary loan.

With respect to protection, the gallery ensures that basic conservation of the collection items takes place each year and, if major interventions are necessary, it makes cooperates with external museums and professional restoration studios. In general, the hotel management appreciates the guests' approach to its collections. High respect and esteem for the works is also an aspect of the relationship with today's visitor, as a participant in tourism, to the visited environment, place, or the artefact itself.

The gallery cooperates with expert consultants, as well as other galleries and museums, archives, painters and collectors. Several activities are organised jointly with other memory institutions in the town of Vysoké Tatry itself.

There is a highly informative documentary film which provides important accompanying information and promotes the hotel. Based on the outcomes of research undertaken by key figures in hotel, the film shows the development of Hotel Lomnica and, by capturing the important economic milestones, provides a brief, yet comprehensive socio-cultural picture of the High Tatras from the twentieth century until today.

It is an important part of our identity, it carries a message, an emotion. (Woman, 36 years)
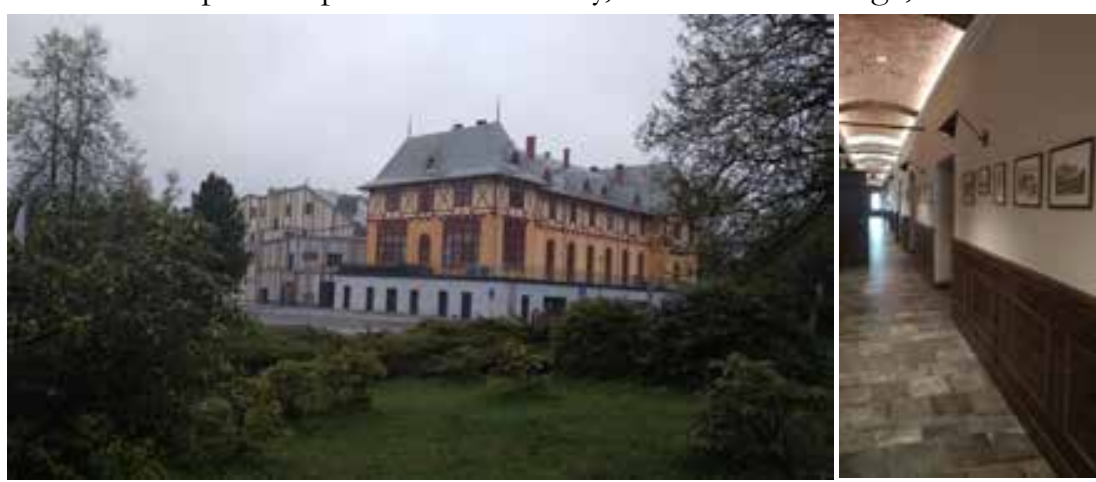

Fig. 7, Fig. 8:

Lomnica Gallery.

Photo: Z.

Krišková, 2020

Lomnica Gallery, as part of the hotel premises, is open not only to hotel guests, but to the general public as well. It offers an original way of presenting of the highest values of Slovakian artistic cultural heritage. It fulfils, in a unique way, the essence of sustainable development of the country's tourism and travel industry by exploiting the exceptional values of its cultural identity. 
The municipality and its contribution to the prosperity of the travel and tourism industry in the High Tatras

In the travel industry, the safeguarding and presentation of cultural values is tied to a certain place, city or town, region or state, the offer of which relates, to a certain degree, to the quality and capacities of the public authorities. ${ }^{26}$ The town of Vysoké Tatry is currently an important co-actor in the shaping of the quality, growth, and sustainability of this phenomenon. Visitors are primarily oriented on tourism and sports. In order to ensure a rich cultural experience, the town also focuses its efforts on meeting visitors' needs for cultural relaxation.

When it comes to developing cultural tourism, the local population plays an important role. In general, little emphasis is placed on this aspect. Nevertheless, it is necessary to build up the local population's positive relationship with original local values. ${ }^{27}$

Activities that encourage this in our study area include the Meeting at Kyselka Spring (Stretnutie pri kyselke), which opens the town of Vysoké Tatry's summer tourist season each year.

The Kyselka Spring is a place shrouded in legends. Through this spring, we interpret the scenic presentation of some legends on the High Tatras, especially on their healing springs and spas. The audience response is also positive, as we dig deep into the cultural essence of the Tatras. (Man, 56 years, representative of the municipality)

The Vysoké Tatry Town Days is a weekend festival that offers space for mutual interactions among members of the community and shows their connection to heritage and local environment. The Tatra Gala Night represents a special feature of this activity, being accompanied by the annual awarding of prizes to outstanding figures in the town. This event takes on a public character by presenting the year's new addition to the Tatra Sports Hall of Fame. Situated within the gallery premises in Vila Flóra, the Hall of Fame has the character of a "mini-museum", presenting to tourists who are learning about the memory of the town one of the dominant aspects of life in the Tatras - sports and sports personalities of both national and international importance.

Nowadays, the municipal authorities of Vysoké Tatry also contribute to the development and sustainability of tourism in the Tatras by partnering with marketing professionals and the national tourism board, being aware of the need for general coordination in promoting tourism in the area.

From the point of view of the much-discussed dilemma of "nature versus tourism", the attitude of the local government is unequivocal:

We are absolutely and fundamentally against any mass events of private companies with up to 30,000 people per day. Visitors have nowhere to park, decibels spread over the mountains (like in Hrebienok). [...] The Tatras are full of nervousness on both sides - visitors as well as nature. (Man, 56 years, representative of the municipality)

\section{Conclusion}

The development of cultural tourism tends to be perceived positively within the given environment, although it is important that it is managed in a sustainable manner. This topic has

\footnotetext{
${ }^{26}$ JAKUBÍKOVÁ, Dagmar. Marketing v cestovním ruchu: Jak uspèt v domácí i svétové konkurenci. 2012, p. 23.

${ }^{27}$ KURPAŠ, Michal, ZIMA, Roman. Manažment a marketing... p. 72.
} 
been discussed by Terzic, Jovičic and Simeunovic-Bajic, among others. ${ }^{28}$ In this context, local identity remains an important factor.

The commercial potential of natural and cultural heritage is increasingly exploited in the field of tourism, representing an important source of income for local, regional and national economies, and one of which representatives of local, regional and state governments are becoming increasingly aware. In this process of commodification, cultural heritage is all too often treated as a type of commercial product, degraded to a mere commodity, bringing its authenticity into question. Even though cultural heritage is a significant source of economic income and growth, its economic value must not outweigh or endanger the real value of the heritage, as emphasised in the Council of Europe's FARO Convention 2005. ${ }^{29}$

This risk is also stressed by MacDonald, whose study on European populations found that people can lose the sense of their own identity and become the victim of the "identity industry" which builds on standardised identity. ${ }^{30}$ The importance of identity issues is very sensitively perceived by the inhabitants of the town of Vysoké Tatry:

It is about the relationship of these people to the Tatras and to their history, about respect for their values [...] Historically - Lomnica, for instance, is some 100 years old, it's all young, people have no relationship to the land; when it was built, people were coming here from elsewhere. For example, it was necessary to quickly build apartment buildings for the World Championships, arrange service staff for hotels, people were recruited from different places, without having any relationship to these hills, not to speak of their children. And it served for nothing. There has been no relationship to the land or to its history. (Man, 52 years)

Even though this study does not focus on the economic factors of the travel industry and tourism in the Tatras, this aspect cannot be fully avoided in the context of this topic.

In the beginning, the spa sector assumed visitors would come for long stays and, hence, enjoy wider opportunities for exploring nature and the local culture, as well as engaging in sports. At present, tourism to the area is characterised by shorter stays, even weekend or oneday trips.

The counterpart to the the activities of small regional entrepreneurs who focus on presenting the High Tatras' cultural capital is the production of mass events promoted widely by large developers which predominantly meet the preferences of one-day visitors. In such cases, priority is given to short-term, commercial mass activities run by large private companies who syphon off most of the economic benefits. These popular, interesting and, at the same time, lucrative events include the winter attraction, the Tatra Ice Dome, ${ }^{31}$ which does have an undoubtedly artistic value, and is accompanied by an international competition in the creation of ice statutes. Another example is the Bear Days at Hrebienok, with all-day attractions aimed at children. ${ }^{32}$

This character of these activities brings contradiction to tourism in the Tatras, with negative impacts on the above-mentioned small private museums that pursue the safeguarding of local

\footnotetext{
${ }^{28}$ TERZIC, Aleksandra, JOVIČIC, Ana, SIMEUNOVIC-BAJIC, Nataša. Community role in heritage management and sustainable tourism development: Case study of the Danube region in Serbia. In: Transylvanian Review of Administrative Sciences. Special Issue/2014, pp. 183-201.

${ }^{29}$ HOPPÁL, Mihály. Trvalo udržatel’né dedičstvo v spoločnosti založenej na tradícii. In: Ocbrana kultúrnebo dedičstva. 2012, p. 51.

${ }^{30}$ MACDONALD, Sharon. Memorylands. Heritage and Identity in Europe Today. 2013, p. 109.

${ }^{31}$ https://slovakia.travel/en/tatra-ice-dome

${ }^{32}$ https://slovakia.travel/en/medvedie-dni-bear-days
} 
and regional values in their cultural identification context.

The large private companies that organise the cultural life here now are based in other towns and centres; their relationship is different. It's not about a person coming and step-by-step, building a reputation here, spinning capital right on the spot. It's about tourists coming here and paying for this and that [...] and the money doesn't stay in the Tatras, it goes to the company which is based in a different place. And it often happens that they don't reinvest the money in the Tatras. (Man, 38 years)

Last year, we already had the feeling that they would tear the Tatras apart, with all that unbearable strain by the businessmen and large companies - where and how much money to grab, what to invent [...] How much money is enough money? Let's keep in mind what kind of place it is, whether we want to have a national park or an amusement park here. (Woman, 32 years)

Nowadays, the travel industry is primarily considered to be an economic sector and, hence, the bearer of economic functions and effects. However, even from the economic perspective, the position of culture, along with the environment, must be significant or even determining. ${ }^{33}$

It is up to the travel industry organisers and actors, with an emphasis on those in local government, to ensure that mass tourism, combined with the prioritisation of economic growth, does not prevail over the preservation of cultural values which form an integral part of the ethnic and cultural identity of the area, but remains in line with the principles of sustainability. The management of culture, destination management and marketing should be synchronised and operate in tandem. An appropriate share of income from the travel industry and visitor activities related to the objects of cultural heritage should be used effectively and fairly to maintain, safeguard, present, and manage them. The sustainable development of cultural and natural heritage sites should thus contribute to the area's social and economic development, which has a crucial impact on the creation of resources for the preservation of the specific features of local culture. ${ }^{34}$

\section{References}

\section{Literature}

BITUŠÍKOVÁ, Alexandra (2018). Kulturne dedičstvo a regionálny rozvoj: Etnologická perspektiva. Banská Bystrica: Matej Bel University in Banská Bystrica, 75 p. ISBN 978-80-973146-5-1.

BOHUŠ, Ivan, st., BOHUŠ, Ivan, ml. (2017). Tatranské osady do r. 1918. In: KOLLÁROVÁ, Zuzana, JANIGOVÁ, Ingrid (eds.): Vysoké Tatry. Vysoké Tatry: Mesto Vysoké Tatry. pp. 43-77. ISBN 978-80-89613-18-2.

DUGULAN, Diana, POPESCU Ioana Cecilia, VEGHES, Calin (2012). An assessment of the relationship between the cultural heritage, travel and tourism, and sustainable development in Central and Eastern European countries. Annals of Faculty of Economics, University of Oradea, Faculty of Economics, 1(1), pages 1141-1147.

GÚČIK, Marián a kol. (2006). Manažment cestovného ruchu. Banská Bystrica: Dali-BB, 224 p. ISBN 80-88945-84-4.

GÚČIK, Marián a kol. (2007). Mana:̌ment regionálneho cestovného ruchu. Banská Bystrica: Dali-BB, 290 p. ISBN 978-80-89090-34-1.

${ }^{33}$ LENOVSKÝ, Ladislav. Cestovný ruch ako kulturologický fenomén. In: Kontexty kultúry a turizmu. 2008, p. 17.

${ }^{34}$ KURPAŠ, Michal, ZIMA, Roman. Manažment a marketing... p. 78. 
HOPPÁL, Mihály (2012). Trvalo udržatel'né dedičstvo v spoločnosti založenej na tradícii. In: HAMAR, Juraj, KYSEL' Vladimír (eds.): Ochrana kultúrneho dedičstva. Zborník zo sympózia. Bratislava: Coordination Centre of Traditional Folk Culture, pp. 39-53. ISBN: 978-70-8121355-0.

CHORVÁT, Ivan (2006). Sociológia turizmu a jej počiatočné východiská. In: ČUKAN, Jaroslav, GAŽIOVÁ, Anna, ŠUSTEKOVÁ, Ivana (eds.): Tradičná kultúra, turižmus a rozvoj regionov. Nitra: Department of the Management of Culture and Tourism of the Faculty of Arts, Constantine the Philosopher University in Nitra; Department of Ethnology and Ethnomusicology of the Faculty of Arts, Constantine the Philosopher university in Nitra, pp. 196-205. ISBN: 80-8050-992-1.

CHRENŠČCVÁ, Viera (2011). Udržatel’ný rozvoj cestovného ruchu v chránenej krajinnej oblasti Horná Orava z pohl'adu aktérov rozhodovacej sféry. In: Acta Universitatis Matthiae Belli, Vol. 13, No.1, pp. 61-67. ISSN 1338-4430. Available at: http://www.fpv.umb.sk/kat/ ken/akta/attachments/article/50/Acta\%202011-13.pdf [2013-02-03]

CHOVANCOVÁ, Barbara 2015. Sprievodca expozíciou múzea TANAP-u. Lublin: Štátne lesy TANAP-u., p. 7.

JAKUBÍKOVÁ, Dagmar (2012). Marketing v cestovním ruchu: Jak uspét v domácí i svètové

konkurenci. Prague: Grada Publishing. 320 p. ISBN 978-80-247-4209-0.

JANIGOVÁ, Ingrid (2017). Spoločenské dianie a kultúra. In: KOLLÁROVÁ, Zuzana, JANIGOVÁ, Ingrid (eds.): Vysoké Tatry. Vysoké Tatry: Mesto Vysoké Tatry. pp. 287-333. ISBN 978-8089613-18-2.

KRIŠKOVÁ, Zdena (2020). Kultúrne dedičstvo - ekonomický zdroj rozvoja turizmu, či odraz kultúrnej identity? In: KLÍMOVÁ, Viktória, ŽÍTEK, Vladimír (eds.): XXIII. Medzinárodné kolokvium o regionálnych vedách. Brno: Masaryk University, pp. 362-370. ISBN 978-80-2109610-3.

KURPAŠ, Michal, ZIMA, Roman (2016). Manažment a marketing kultúrneho dedičstva. In: KRIŠKOVÁ, Zdena (ed.): Kultúrne dedičstvo a identita. Banská Bystrica, Department of Social Studies and Ethnology of the Faculty of Arts, Matej Bel University in Banská Bystrica, pp. 71-79. ISBN 978-80-557-1120-1.

KVASNIČKA, Marián (2017). Úvodné slovo k zbierke. In: Galéria Lomnica 2017 (Umelecká zbierka v priestoroch hotela Lomnica). Tatranská Lomnica: Lomnica Gallery. 369 p. ISBN 97880-972533-2-5.

LENOVSKÝ, Ladislav (2008). Cestovný ruch ako kulturologický fenomén. In: LETAVAJOVÁ, Silvia (ed.): Kontexty kultury a turizmu. Nitra: Department of the Management of Culture and Tourism of the Faculty of Arts, Constantine the Philosopher University in Nitra, Year 1, 2008, No. 1, pp. 17-22. ISSN 1337-7760.

MACDONALD, Sharon (2013). Memorylands. Heritage and Identity in Europe Today. London and New York: Routledge. p. 109. ISBN 978-0415453349

NOVÁKOVÁ, Katarína (2015). Tatranski nosiči. Vysoké Tatry: I\&B. 94 p. ISBN 9788089575077. ŠTURCEL, Marián (2017). Príroda Tatier. In: KOLLÁROVÁ, Zuzana, JANIGOVÁ, Ingrid (eds.): Vysoké Tatry. Vysoké Tatry: Mesto Vysoké Tatry. pp. 15-29. ISBN 978-80-89613-18-2. 
TERZIC, Aleksandra, JOVIČIC, Ana, SIMEUNOVIC-BAJIC, Nataša (2014). Community role in heritage management and sustainable tourism development: Case study of the Danube region in Serbia. In: Transylvanian Review of Administrative Sciences. Cluj-Napoca, Rumunsko: Babes-Bolyai University, Faculty of Political, Administrative and Communication Sciences. Special Issue/2014, pp. 183-201. ISSN 1842-2845

TIŠLIAR, Pavol (2016). Muzeológia na Slovensku. In: Muzeológia a kultúrne dedičstvo. Bratislava: Comenius University, Faculty of Arts. 1, pp.127-135. ISSN 1339-2204.

TOADER, Cosmina-Simona, SAMBOTIN Dana, GHERMAN, Dana (2013). Aspects regarding cultural tourism development in Timis county through projects. In: Agricultural Management /Lucrari Stiintifice Seria I. 15(4), pp. 56-63. ISBN 978-80-88064-09-1.

\section{Internet sources}

Ministry of Culture of the Slovak Republic. Register of Museums and Galleries of the Slovak Republic. http://195.49.188.210/kulturne-dedicstvo/muzea-a-galerie/register-muzei-a-galeriislovenskej-republiky [cited on 14/06/2020]

Wander Book. https://sk.wander-book.com/myslienka-projektu.htm [cited on 10/06/2020]

Švajčiarsky dom (Swiss House). https://www.sherpacaffe.sk/sherpa-muzeum/[cited on 13/07/2020] 